\title{
Analysis of the efficiency of public policies in municipalities, with a population of over 10.000 habitants in the administrative region of Presidente Prudente - Data from COVID-19
}

\author{
Prof. Dr. Moises da Silva Martins
}

Faculdde de Tecnologia de Presidente Prudente

Received: 11 Mar 2021; Received in revised form: 01 May 2021; Accepted: 18 May 2021; Available online: 29 May 2021

\begin{abstract}
Pandemics, such as that of COVID-19, affect a large number of people, imposing new rules and social habits on them, aiming to modify the behavior that influences economic and social problems. In this context, the objective of this study was to be investigative, using the DEA tool (data envelopment analysis), seeking the efficiency of proposed and economic measures, seeking to assist them and also public policies in improving planning, trying to avoid problems such as those caused by the current pandemic. This is a cross-sectional and quantitative study, of an exploratory nature, carried out with data from the 10th. Region of the state of São Paulo, based on municipalities with 10,000, or more, inhabitants in the time interval from 05/03/2020 to 05/05/2021. This work is justified by the fact that the COVID-19 pandemic exposes structural weaknesses, economic differences and bottlenecks in the Brazilian health system, especially the lack or uneven distribution, in the territory, of health professionals and health professional, infrastructure, as well as limited production capacity, poor income distribution, the human development index and, still, the glaring differences in the GDP of the municipalities. It has been noted that $53 \%$ of the municipalities are deficient and that only $47 \%$ of them are above the average ideal efficiency rate of 0.823150. It is concluded, in this work, that the economic and social factors need to be better addressed and that social distance, the use of masks and personal hygiene must be encouraged by the representatives of the public power, in order to avoid a greater number of deaths.
\end{abstract}

Keywords-COVID-19. Data envelopment analysis. Economy. Pandemic.

\section{INTRODUCTION}

The year 2020 brought worries to the whole world. The covid-19 pandemic has caused many difficulties in the lives of millions of people. Many died, many were contaminated and suffered serious consequences, making their lives much more difficult. . In all countries, the poorest people have suffered the greatest impacts, losing jobs and income. The covid-19 pandemic is believed to have exposed and increased economic inequalities everywhere.

It is well known that the COVID-19 epidemic found the Brazilian population in a situation of extreme vulnerability, with high unemployment rates and deep cuts in social policies. Over the past few years, especially after the approval of Constitutional Amendment No. 95, which imposes a radical ceiling on public spending and with the economic policies implemented by the current Government, there is a growing and intense bottleneck in investments in health and research in Brazil.

Pandemics are known as epidemics that spread quickly to different countries and affect a relatively large number of people and, in general, generate consequences of a high level of difficulties for the population, imposing, for the time that they last, new social rules and habits, as

This article can be downloaded from here: $\underline{w w w . i j a e m s . c o m}$ 
well as mobilizations of different kinds for their containment.

According to data from the World Health Organization (WHO), the outbreak of COVID-19 began in China in December 2019. Since then, it has been reaching different places and populations.

With regard to social aspects, the Ministry of Health issued a series of recommendations to the population, in order to inform them about issues of transmission, prevention and procedures in case of contagion of the disease.

One of the main consequences, in this sense, was the social distance as a measure to prevent the spread of COVID-19, being all she was oriented about the need to leave their homes only in case of extreme need, such as going to the market, pharmacies or health care.

For Wilder-Smith and Freedman, (2020), a distinction must be made between social distance, social isolation and quarantine. The distance, still according to Wilder-Smith and Freedman (2020), refers to the effort to reduce contacts and physical approximation between people in a population, in order to reduce the speed of contagion; isolation as a way of separating people already infected from those who are asymptomatic; and quarantine as a way to mitigate the movement of people who may have been potentially exposed to the disease. However, these three concepts are often used interchangeably, as a way of communicating to the population in an easy to understand manner.

In this work, we investigated, using the DEA tool (data envelopment analysis), how the efficiencies of proposed measures and economic measures could have helped public policies in improving planning and avoided the problems caused by the pandemic.

One of the advantages of using DEA, according to Guedes (2002), is that DEA, as it is a non-parametric evaluation method, has different characteristics in relation to other methods. In contrast to parametric methods, whose objective is to improve a simple regression plan, the DEA individually improves each of the observations, one in relation to the others, in order to determine the efficiency frontier. Parametric and traditional analysis applies the same production function to each of the observations. Therefore, the DEA's focus is on " $n$ " optimizations, in contrast to the parameter estimates of the statistical approximations used by other methods.

In order to ascertain the objectives, the tenth administrative region, based in Presidente Prudente, was taken into account. And, with the help of the choice of main components, municipalities with a population above
10.000 habitants were studied, taking into account, as input, the area in question. square kilometers, which served to analyze social distance; the human development index (HDI), which served to assess the quality of life of the inhabitants; the gross domestic product (GDP), which aims to show the importance of the wealth of the municipality and what consequences they brought to the outputs, such as the number of cases and deaths for the population of the municipalities in studies and how the related studies of these items can contribute to efficient and effective public planning.

This work is justified by the fact that the COVID19 pandemic exposes structural weaknesses, economic differences and bottlenecks in the Brazilian health system, in particular the lack or uneven distribution, in the national territory, of health professionals and infrastructure, as well as limited production capacity and poor income distribution, the human development index, as well as the stark differences in the GDP of the municipalities.

\section{DEVELOPMENT}

\subsection{COVID-19 in Brazil}

COVID-19 is a disease caused by the SARSCoV-2 corona virus, which, for Wilder (2020), presents a clinical picture that ranges from asymptomatic infections to severe respiratory conditions. According to the World Health Organization (WHO), most patients with COVID19 (about $80 \%$ ) may be asymptomatic and about $20 \%$ of cases may require hospital care, as they have difficulty breathing. And, of these cases, approximately 5\% may need support for the treatment of respiratory failure (ventilatory support).

According to WHO (2020), the first case of COVID-19 in Brazil, was confirmed on February 26, 2020. It was an elderly man residing in São Paulo / SP, who had returned from a trip to Italy. The disease spread quickly. In less than a month, after the confirmation of the first case, there was already community transmission in some cities. On March 17, 2020, the first death from COVID-19 occurred in the country. He was another elderly man living in São Paulo / SP, who had diabetes and hypertension, with no history of traveling abroad. On March 20, 2020, the community transmission of Covid-19 was recognized throughout the national territory.

According to the Ministry of Health (2020) on March 5, 2020, at the beginning of the introduction of the disease in the country, cases were mostly imported and the strategy to contain the epidemic was based on the search and isolation of cases and contacts, to avoid transmission of the virus from person to person, in a sustained manner. 
With the increasein the number of cases ofCovid-19 and the occurrence of community transmission, mitigation strategies began to be adopted, seeking to avoid the occurrence of serious cases and deaths from the disease. Such strategies included hospital care measures for severe cases, as well as isolation measures for mild cases and contacts, social isolation and use of gel alcohol with hand hygiene instructions.

\subsection{COVID-19 in the study region}

The first case of COVID in Presidente Prudente, headquarters of the tenth administrative region, according to the Municipal Health Secretariat, took place on March 6,2020 . This was a 23-year-old girl, a student in the health field in the city of São Paulo .

On March 4, the young woman came to Presidente Prudente and, two days later, began to show symptoms characteristic of the disease. When looking for a health unit, it was found that there was no need for hospitalization and the patient was instructed to remain in social isolation for 14 days.

The patient confirmed with the new corona virus fulfilled social isolation during the 14 days, so she avoided contact with other people during the virus incubation period, as reinforced by the City Hall. From there, there was a need to channel attention to the non-dissemination of the virus.

\subsection{Data Envelopment Analysis (DEA)}

Data Envelopment Analysis is a mathematical programming tool designed to assess the relative efficiency of production units in a homogeneous set of organizational units, called Decision Making Units (DMUs), which use similar technological processes, to transform the same inputs and product resources, but differ in the amount of inputs used (inputs) and goods produced (outputs) (BANKER et al., 1984; COOPER and SCHINDLER, 2004; RAY, 2004; COOK and ZHU, 2008).

Efficiency is the comparison of the results achieved with the resources used. The more "results" obtained for a given amount of available resources, the greater the organizational efficiency.

According to Fraser and Cordina (1999), the DEA generates a performance analysis system, which explicitly shows the relationship between several inputs and outputs, simultaneously. This is a more consistent multicriterial measure of efficiency than the most common mono-critical indicators used in evaluating the performance of other products.

\subsection{DEA models used in research}

Two basic DEA models were used as references for measures of technical efficiency at scale: the CCR model and the BCC model.

The CCR model (acronym originating from the authors Cooper, Charnes and Rhodes), also called CRS (Constant Returns to Scale), has as its main property, the proportionality between inputs and outputs at the border. That is, they adopt the hypothesis of constant returns to scale, considering that the proportional growth of the inputs will produce proportional growth of the outputs.

The BCC model (acronym from the authors Banker, Charnes and Cooper) also known as VRS (Variable Returns to Scale), is considered an innovation of the CCR model. It was presented in 1984 (BANKER et al., 1984 ) in order to analyze economies with variable returns to scale (CHARNES et al., 1978; COOPER and SCHINDLER, 2004; RAY, 2004; LINS and CALÔBA, 2006; COOK and ZHU , 2008; FERREIRA and GOMES, 2009). In the BCC model, the proportionality observed in the CCR model, between inputs and outputs, is not considered. In this model, a DMU will be efficient, if it better takes advantage of the inputs, considering the scale of operation, while, in the CCR model, the DMU is considered efficient, when better to use the inputs, without considering its scale of operation (BANKER et al., 1984).

\section{METHOD}

This study, according to Yin (2015), is crosssectional and quantitative, of an exploratory nature, carried out with data from the tenth region of the state of São Paulo, considering municipalities with a quantity of 10 thousand or more inhabitants in the time interval of March 5, 2020 , until March 5, 2021. This research integrates a study by the researcher and scholar in social economic problems with the use of DEA.

The initial part of this study, as reported, began on March 5, 2020 and ended on March 5, 2021. And it is currently underway, with the aim of studying economic measures that will inform and help Brazilian public managers of different regions of the country in decisionmaking.

For this study, however, we opted for the investigation of some variables that are relevant to its cut. The choice of using the data is due, only, to the use of the tool of main components in DEA to have pointed a great difference in measures of social distance, hygiene in the municipalities with population with more than 10.000 habitants.

\section{ANALYSIS PROCEDURE}

This article can be downloaded from here: www.ijaems.com 
The analysis procedure was based on DEA associated with the Integrated Decision Support System (SIAD), due to the versatility of the software in order to reduce the number of inputs, as suggested in Abreu (2004).

According to Martins (2015), to give consistency to the conclusion, the arithmetic average of the standard efficiency of the BCC and CCR models is considered, and the municipalities that present efficiency above the average will be considered with public and growing policies. And the others, with below average efficiency, will be considered decreasing, that is, with inefficient public policies.

Table 1 contains data showing the inputs (population, area, GDP and HDI) and the outputs (cases of infected, percentage and total number of deaths) between March 5, 2020 until March 5, 2021.

Table 1- data for the study of efficiencies

\begin{tabular}{|l|l|l|l|l|l|l|l|}
\hline Cidades & População & Área Km & $\begin{array}{l}\text { PIB/18 (R } \$ \text { ) } \\
\text { anual }\end{array}$ & IDH & Casos & \%mortos & Mortes \\
\hline Adamantina & 35.111 & 411.781 & $1,084.405,13$ & 0,790 & 2003 & 2,45 & 49 \\
\hline Álvares Machado & 24.813 & 347.647 & $530.717,81$ & 0,758 & 1009 & 2,18 & 22 \\
\hline Dracena & 45.847 & 488.041 & $720.338,00$ & 0,776 & 3894 & 4,16 & 162 \\
\hline Martinópolis & 26.123 & 1.253 .564 & $496.100,11$ & 0,721 & 884 & 3,96 & 35 \\
\hline $\begin{array}{l}\text { Mirante } \\
\text { doParanapanema }\end{array}$ & 18.130 & 1.238 .931 & $345.876,15$ & 0,724 & 416 & 3,13 & 13 \\
\hline Osvaldo Cruz & 32.593 & 247.941 & $309.960,23$ & 0,776 & 1278 & 3,29 & 42 \\
\hline Pirapozinho & 27.021 & 477.675 & $950.942,90$ & 0,776 & 1537 & 2,54 & 39 \\
\hline PresidenteBernardes & 13,420 & 749.233 & $270.320,30$ & 0,757 & 668 & 2,84 & 19 \\
\hline Presidente Prudente & 225.271 & 560.637 & $7.994 .539,21$ & 0,806 & 15234 & 2,7 & 411 \\
\hline Quatá & 13.893 & 651.341 & $460.246,49$ & 0,738 & 831 & 1,56 & 13 \\
\hline Rancharia & 29.821 & 1.587 .498 & $1.105 .058,95$ & 0,751 & 1895 & 1,43 & 27 \\
\hline Regente Feijó & 20.394 & 265.087 & $710.647,43$ & 0,768 & 391 & 6,91 & 27 \\
\hline Rosana & 16.281 & 741.216 & $1.195 .602,74$ & 0,764 & 772 & 1,94 & 15 \\
\hline Santo Anastácio & 21.030 & 552.876 & $412.908,13$ & 0,753 & 572 & 2,97 & 17 \\
\hline Teodoro Sampaio & 22.914 & 1.555 .803 & $437.472,13$ & 0,741 & 1156 & 1,47 & 17 \\
\hline Author-Painel cor & & & & & & \\
\hline
\end{tabular}

Source: Author-Painel coronavírus

Table 2 shows the quantitative of the efficiencies, results found using the BCC model, oriented for input.

Table 2- Efficiency ratios using BCC

\begin{tabular}{|l|l|l|l|l|}
\hline DMU & Padrao & Invertida & Composta & Composta* \\
\hline Adamantina & 0,965216 & 1,000000 & 0,482608 & 0,948205 \\
\hline A.Machado & 1,000000 & 0,982059 & 0,500000 & 0,982375 \\
\hline Dracena & 1,000000 & 1,000000 & 0,508970 & 1,000000 \\
\hline Martinóplis & 1,000000 & 1,000000 & 0,500000 & 0,982375 \\
\hline M.Paranapanema & 1,000000 & 1,000000 & 0,500000 & 0,982375 \\
\hline Oswaldo Cruz & 1,000000 & 1,000000 & 0,500000 & 0,982375 \\
\hline Pirapozinho & 0,974085 & 0,993824 & 0,490131 & 0,962964 \\
\hline Pres.Bernardes & 1,000000 & 0,997871 & 0,501065 & 0,984467 \\
\hline Pres.Prudente & 1,000000 & 1,000000 & 0,500000 & 0,982375 \\
\hline Quatá & 1,000000 & 1,000000 & 0,500000 & 0,982375 \\
\hline
\end{tabular}

This article can be downloaded from here: www.ijaems.com 


\begin{tabular}{|l|l|l|l|l|}
\hline Rancharia & 0,989443 & 1,000000 & 0,494721 & 0,972004 \\
\hline Reg.Feijó & 1,000000 & 1,000000 & 0,500000 & 0,982375 \\
\hline Rosana & 0,965166 & 1,000000 & 0,482583 & 0,948155 \\
\hline S.Anástácio & 0,998074 & 1,000000 & 0,499037 & 0,980483 \\
\hline Teod.Sampaio & 0,994126 & 1,000000 & 0,497063 & 0,976605 \\
\hline
\end{tabular}

Source: Author

Table 3 shows the quantitative of the efficiencies, results found using the CCR model, oriented for input

Table 3- Efficiency ratios using CCR

\begin{tabular}{|l|l|l|l|l|}
\hline DMU & Padrao & Invertida & Composta & Composta* \\
\hline Adamantina & 0,693596 & 0,898295 & 0,397651 & 0,573715 \\
\hline A.Machado & 0,587867 & 1,000000 & 0,293934 & 0,424076 \\
\hline Dracena & 1,000000 & 0,613770 & 0,693115 & 1,000000 \\
\hline Martinóplis & 0,845757 & 0,898359 & 0,473699 & 0,683435 \\
\hline M.Paranapanema & 0,884332 & 1,000000 & 0,442166 & 0,637940 \\
\hline Oswaldo Cruz & 1,000000 & 1,000000 & 0,500000 & 0,721381 \\
\hline Pirapozinho & 0,750541 & 0,838660 & 0,455941 & 0,657813 \\
\hline Pres.Bernardes & 1,000000 & 0,997871 & 0,539624 & 0,778548 \\
\hline Pres.Prudente & 1,000000 & 0,920753 & 0,500000 & 0,781381 \\
\hline Quatá & 0,769404 & 1,000000 & 0,384702 & 0,555033 \\
\hline Rancharia & 0,748173 & 1,000000 & 0,374086 & 0,539718 \\
\hline Reg.Feijó & 1,000000 & 1,000000 & 0,500000 & 0,721381 \\
\hline Rosana & 0,724886 & 1,000000 & 0,362443 & 0,522919 \\
\hline S.Anástácio & 0718857 & 1,000000 & 0,359429 & 0,518570 \\
\hline Teod.Sampaio & 0,618928 & 1,000000 & 0,309464 & 0,446482 \\
\hline
\end{tabular}

Source: Author

Table 4 shows the average number of standard efficiencies, results found, using the CCR and BCC models, oriented for input.

Table 4; Averages of standard efficiencies between CCR and BCC

\begin{tabular}{|l|l|l|l|l|}
\hline DMU & CCR & BCC & CCR/BCC & Eficiência de escala \\
\hline Adamantina & 0,693596 & 0,965216 & 0,718591 & Decrescent \\
\hline A.Machado & 0,587867 & 1,000000 & 0,587867 & Decrescent \\
\hline Dracena & 1,000000 & 1,000000 & 1,000000 & Crescent \\
\hline Martinóplis & 0,845757 & 1,000000 & 0,844332 & Crescent \\
\hline M.Paranapanema & 0,884332 & 1,000000 & 0,884332 & Crescent \\
\hline Oswaldo Cruz & 1,000000 & 1,000000 & 1,000000 & Crescent \\
\hline Pirapozinho & 0,750541 & 0,974085 & 0,770509 & Decrescent \\
\hline Pres.Bernardes & 1,000000 & 1,000000 & 1,000000 & Crescent \\
\hline Pres.Prudente & 1,000000 & 1,000000 & 1,000000 & Crescent \\
\hline
\end{tabular}

This article can be downloaded from here: www.ijaems.com 


\begin{tabular}{|l|l|l|l|l|}
\hline Quatá & 0,769404 & 1,000000 & 0,769404 & Decrescent \\
\hline Rancharia & 0,748173 & 0,989443 & 0,788013 & Decrescent \\
\hline Reg.Feijó & 1,000000 & 1,000000 & 1,000000 & Crescent \\
\hline Rosana & 0,724886 & 0,965166 & 0,751048 & Decrescent \\
\hline S.Anástácio & 0718857 & 0,998074 & 0,720244 & Decrescent \\
\hline Teod.Sampaio & 0,618928 & 0994126 & 0,622585 & Decrescent \\
\hline average & & & 0,823150 & \\
\hline
\end{tabular}

Source: Author

\section{RESULTS}

The sample consisted of 15 municipalities that served as a basis for the study of components that assist decisions in public policies.

The municipalities that showed prominence in the efficiency of public policies, in relation to COVID-19, were classified with an average above 0.823150 . By this criterion, the municipalities of Presidente Prudente, Presidente Bernardes, Regente Feijó, Mirante do Paranapanema, Martinópolis and Dracena were classified. It is worth mentioning that the municipalities of Martinópolis and Mirante do Paranapanema need a little more attention, because, even though they are above average, they are below index 1 , which is considered satisfactory.

The municipalities of Rancharia, Pirapozinho, Quatá, Rosana, Santo Anastácio, Adamantina, Teodoro Sampaio and Álvares Machado were rated efficiently below 0.823150 , which presupposes that there is a need for improvement in public policies and that, in a general aspect of this analysis, the municipalities of Alvares Machado and Santo Anastácio need a little more attention from those in charge of public policies, with regard to social actions on COVID.

The equation, in DEA, shows, with assertive property, the existing correlation between the studied items. Some limitations of this study relate to the sample's scope, and it is not possible to generalize the results found here beyond the participants of this study. Generalizations are not possible for the rest of the municipalities in the state or country.

\section{FINAL CONSIDERATIONS}

At the moment, public policy decisions must be associated in the quest to save lives, guaranteeing safe, efficient information and providing recovery assistance to infected patients, since the COVID-19 pandemic reached the population in a situation of extreme vulnerability, with very high unemployment rates and low investments in social policies.

Considering that $53 \%$ of the municipalities are in deficit and only $47 \%$ are above the average ideal efficiency rate of 0.823150 , it is concluded, in this work, that the economic and social factors need to be better addressed; and social distancing, wearing a mask and personal hygiene need to be studied and guided by the representatives of the public power, in order to avoid a greater number of deaths; and that the municipalities considered ineffective here will overcome this pandemic period and the others considered efficient will continue to increase efficiency.

\section{REFERENCES}

[1] ABREU, U. G .P. Análise da adoção de tecnologias em sistema extensivo de criação de gado de corte no Pantanal: um estudo de caso. Viçosa, MG: Universidade Federal de Viçosa, 2004. 134p. Dissertação (Doutorado em Zootecnia) - Universidade Federal de Viçosa, 2004.

[2] BANKER, R.; CHARNES, A.; COOPER, W.W.Some models for estimating technical and scale inefficiencies in data envelopment analysis.Management Science, v.30, p.1078-1092, 1984.

[3] Brasil. Ministério da Saúde (MS). Painel coronavírus Atualizada em 08 de maio de 2020. [acessado em 2020 Maio 9]. Disponível em: https://covid.saude.gov.br/ » https://covid.saude.gov.br/

[4] Brasil. Ministério da Saúde (MS). Brasil confirma primeiro caso da doença [acessado em 202025 de Abr]. Disponível em: https://www.saude.gov.br/notícias/agenciasaude/46435-brasil-confirma-primeiro-caso-de-novocoronavírus

$\gg$ https://www.saude.gov.br/noticias/agencia-saude/46435brasil-confirma-primeiro-caso-de-novo-coronavirus

[5] «Brasil registra 1.546 casos de coronavírus e 25 mortes». Jovem Pan. 22 de março de 2020. Consultado em 22 de março de 2020

[6] CHARNES, A.; COOPER, W. W.; RHODES, E. Measuring the efficiency of decision making units. European Journal of Operational Research, v.2, p.429444, 1978.

This article can be downloaded from here: www.ijaems.com 
[7] Coronavírus - Dados Completos». seade.gov.br. Consultado em 28 de maio de 2020

[8] FRASER, I.; CORDINA, D.An Application of Data Envelopment Analysis to Irrigated Dairy Farms in Northern Victoria.Australia.Agricultural Systems, v. 59, p. 267-282, 1999.

[9] Gonçalves DM, Stein AT, Kapczinski F. Avaliação de desempenho do Self-Reporting Questionnaire como instrumento de rastreamento psiquiátrico: um estudo comparativo com o Structured Clinical Interview for DSM-IV-TR. Cad Saude Publica 2008; 24(2):380-390.

[10] Governo de SP diz que prefeita de Bauru é mau exemplo na pandemia». O Antagonista. 6 de março de 2021. Consultado em 7 de março de 2021

[11] GUEDES, L. E. M. Uma análise da eficiência na formação de alunos dos cursos de engenharia civil das instituições de ensino superior brasileiras. 2002. 130p. Dissertação (Mestrado em Engenharia de Produção) Universidade Federal do Rio de Janeiro. Rio de Janeiro, 2002.

[12] In Loco. Mapa brasileiro da COVID-19. Índice de isolamento social [acessado 2020 Abr 20]. Disponível em: https://mapabrasileirodacovid.inloco.com.br/pt/? hsCtaTracking $=68943485-8 \mathrm{e} 65-4 \mathrm{~d} 6 \mathrm{f}-8 \mathrm{ac} 0-\mathrm{af} 7 \mathrm{c} 3 \mathrm{ce}$ 710a2\%7C45448575-c1a6-42c8-86d9-

c68a42fa3fcc.»https://mapabrasileirodacovid.inloco.com.br /pt/? hsCtaTracking=68943485-8e65-4d6f-8ac0-af7c3ce 710a2\%7C45448575-c1a6-42c8-86d9-c68a42fa3fcc

[13] OMS reforça lista de critérios que países devem analisar antes de suspender isolamento contra Covid-19». G1. Consultado em 06 de março de 2021

[14] Martins, M.S.Herrera, H.M. Metodologia- Pluralidade científica. Análise envoltória de dados-Modelo para avaliação de eficiênciaprodutiva e sustentável, 2015, pág.53 à 60. ed;CRV-Curitiba

[15] Wilder-Smith A, Freedman DO. Isolation, quarantine, social distancing and community containment: pivotal role for old-style public health measures in the novel coronavirus (2019-nCoV) outbreak. J Travel Med 2020; 27(2):taaa020.

[16] YIN, Robert K. Estudo de Caso: Planejamento e Métodos.Tradução: Daniel Grasi. 2. ed., Porto Alegre: Bookman, 2001 